\title{
O discurso em situação de entrevista política: posicionamento e estratégias dos atores políticos
}

\author{
THE SPEECH IN A POLITICAL IN A INTERVIEW SITUATION: \\ POSOTION AND STRATEGIES OF THE POLITICAL ACTORS
}

\section{- Rejane de Oliveira Pozobon}

Docente do Programa de Pós-Graduação em Comunicação da Universidade Federal de Santa Maria. Professora Associada do Departamento de Ciências da Comunicação da Universidade Federal de Santa Maria. Doutora em Ciências da Comunicação pela Universidade do Vale do Rio dos Sinos (2007), Mestre em Educação pela Universidade Federal de Santa Maria (2002), Bacharel em Jornalismo pela Universidade Federal de Santa Maria (2000) e Bacharel em Relações Públicas pela Universidade Federal de Santa Maria (1998). Líder do Grupo de Pesquisa “Comunicação e Política” (UFSM/CNPq). E-mail: rejane.op@terra.com.br.

\section{Marizandra Rutilli}

Doutoranda do Programa de Pós-Graduação em Comunicação da Universidade Federal de Santa Maria.

E-mail: maryrutilli@hotmail.com

Recebido em 09/04/2018. Aprovado em 19/09/2018.

\section{Resumo}

Partimos do entendimento de que o rádio é um "ator político" capaz de incidir em processos de decisão no sistema político (BORRAT, 1989). A entrevista política, mais especificamente, revela-se como um espaço de análise dos recursos e das estratégias tanto do discurso midiático quanto do discurso político. Enquanto "palavra pura e palavra questionada" (CHARAUDEAU, 2012), comparadas a um “jogo de esgrima” (PIATTI, 2019), com estratégias de ataque e contra-ataque entre os envolvidos, se vale da dramaturgia, encenando o ethos por meio de procedimentos linguísticos expressivos e enunciativos (CHARAUDEAU, 2015).

Palavras-chave: Discurso. Entrevista política. Atores políticos.

\section{Abstract}

We start from the understanding that radio is a "political actor" capable of influencing decisionmaking in the political system (BORRAT, 1989). The political interview reveals itself as a space for the analysis of the resources and strategies of both the media and the political discourse. As much as "pure word and questioned word" (CHARAUDEAU, 2012), it is compared to a "fencing match" (PIATTI, 2019), with attack and counter-attack strategies among those involved. It utilizes role-playing by staging ethos through expressive and enunciative linguistic procedures (CHARAUDEAU, 2015).

Keywords: Speech. Political interview. Political actors. 


\section{Considerações iniciais}

Grande parte das narrativas dos acontecimentos políticos chega à esfera civil através dos meios de comunicação. Com isso, a mídia torna-se responsável pela maioria das informações que circulam sobre candidaturas e acontecimentos políticos em ano de campanha eleitoral. As entrevistas possuem uma parcela significativa de contribuição nesse quesito, são espaços para analisar estratégias tanto do discurso midiático quanto do discurso político.

Neste artigo centramos nossa atenção na entrevista que a Rádio Gaúcha ${ }^{1}$ realizou com Alexandre Padilha (vice-presidente do Partido dos Trabalhadores), em 22 de janeiro de 2018, no programa Gaúcha Atualidade² , durante a semana de julgamento do ex-presidente Luiz Inácio Lula da Silva (Lula) ${ }^{3}$.

Com base em Borrat (1989), entendemos que o rádio é um ator político, uma vez que é capaz de afetar (pelo âmbito da influência) processos de decisão no sistema político. Faz uso de estratégias (públicas e privadas) pelo viés da ação humana (equipes produtivas) e, ao apresentar a informação, insere finalidades, aprofundamentos e orientações para a audiência. As entrevistas são parte das estratégias públicas do rádio enquanto ator político já que sua materialização é a produção de um discurso a partir de trocas sociais entre os envolvidos. A palavra pura e questionada é o discurso proferido, tanto por candidatos e/ou políticos (entrevistados) como por jornalistas (entrevistadores).

Nosso aporte teórico-metodológico e posteriores categorias de análise dos discursos são construídos com base em Charaudeau (2012 e 2015). O autor apresenta as técnicas e finalidades do discurso midiático, bem como, mostra as estratégias e recursos do discurso político. O discurso midiático tem dois mecanismos centrais: a visada da informação e da captação. O discurso político, por sua vez, se vale primordialmente do triângulo da dramaturgia (emoções, paixões) encenando o ethos (imagem) por meio de procedimentos linguísticos (expressivos e enunciativos). Consideramos também a contribuição de Piatti (2009), na qual as entrevistas políticas carregam maior nível de polêmica e são comparadas a um jogo de esgrima, estratégias de ataque e contra-ataque.

1. Emissora líder de audiência na Grande Porto Alegre (RS). Em 2017 completou 90 anos.

2. Principal programa de política e economia da Rádio Gaúcha. Está no ar há 40 anos.

3. Em julho de 2017, o ex-presidente foi condenado pelo juiz Sérgio Moro a nove anos e seis meses de prisão por lavagem de dinheiro. A acusação foi de que Lula ocultou a propriedade de um tríplex recebido como propina da empreiteira OAS. Em janeiro de 2018, num julgamento em segunda instância, a defesa do ex-presidente tentou reverter a sentença no Tribunal Regional Federal da $4^{\mathrm{a}}$ Região (TRF4). No entanto, a decisão no TRF4 manteve a condenação e ainda ampliou a pena de nove para doze anos. 
$\mathrm{O}$ artigo está dividido em quatro partes. Primeiramente trazemos uma breve explanação das características e especificidades do discurso das mídias e do político. Em seguida, conceituamos entrevistas políticas, atentando para as especificidades da linguagem do rádio. Em um terceiro momento, apresentamos a análise da entrevista realizada com o vice-presidente do PT, Alexandre Padilha. Por fim, as considerações finais.

\section{O discurso das mídias e o discurso político}

Entender as estratégias discursivas de jornalistas e figuras políticas em situação de entrevista é considerar que mídia e políticos têm um discurso próprio. Pelo viés midiático Charaudeau (2012) sustenta a ideia de que toda informação é um universo construído a partir dos fenômenos sociais, com linguagem racional e sedutora para despertar na audiência a afetividade. Aciona certas estratégias para reportar acontecimentos, comentar, provocá-los. Indiferente do suporte organizacional e especificidade, a mídia é uma máquina midiática (produz informações numa perspectiva comercial), que propõe um contrato comunicacional. Ela liga as demais esferas sociais (política e civil) e cria situações de comunicação para a visibilidade social (CHARAUDEAU, 2012). Para alcançar o maior número de indivíduos, o campo político recorre à esfera midiática e aceita as normativas do contrato de comunicação.

As mídias situam-se num campo de poder complexo que entrecruza vários outros campos cujo ponto comum é o famoso alvo da maioria: o campo do político diante do qual as mídias se legitimam por uma dupla ação, de contra poder, ao opor-se a esse campo, e de interface com a sociedade civil, o que as leva a denunciar; o campo do econômico, no qual as mídias se legitimam por sua capacidade de alcançar o grande público, o que as leva a dramatizar; o campo da cidadania, no qual as mídias se legitimam por uma aptidão em realizar um projeto de construção da opinião pública, o que as leva a serem credíveis. Na tensão entre os polos de credibilidade e de captação, quanto mais as mídias tendem para o primeiro, cujas exigências são as da austeridade racionalizante, menos tocam o grande público; quanto mais tendem para a captação, cujas exigências são as da imaginação dramatizante, menos credíveis serão. As mídias não ignoram isso, e seu jogo consiste em navegar entre esses dois polos ao sabor de sua ideologia e da natureza dos acontecimentos (CHARAUDEAU, 2012, p. 92-93). 
Para Charaudeau (2012) a mídia (dispositivo) impõe restrições no ato de comunicação e na formatação da mensagem que se dá num determinado ambiente físico. É parte do contrato de comunicação que permite a interpretação das mensagens ainda que já formatadas. Aqui se dão os jogos de poder entre as esferas. O campo político tenta manipular a opinião pública a partir de suas estratégias discursivas, no espaço público midiático. Ao mesmo tempo as mídias tentam criar um contra poder. O grande desafio é apreender as diferentes estratégias que tornam esse jogo simbólico perceptível. Para Charaudeau (2012) as mídias manipulam, mas também são manipuladas.

Cada meio de comunicação, enquanto dispositivo, formata os discursos e também os tipos de disputas entre as esferas. É daí que se explicam e se estabelecem as restrições dos textos em formas de discursos, que carregam combinações específicas de fala para uma comunidade social. Um debate televisivo ou radiofônico, ainda que fosse com os mesmos mediadores e figuras políticas, terá um discurso diferente em cada dispositivo. Segundo Charaudeau (2012, p. 34) "a informação implica processo de produção de discurso em situação de comunicação". Toda informação é uma enunciação com escolhas não só de conteúdo, formas de falar, escolhas de efeitos de sentido, estratégias discursivas. Ainda que as outras esferas estejam submetidas ao acordo prévio do contrato midiático, para Charaudeau (2012), há uma mecânica própria de construção de sentido, natureza do saber e efeito de verdade. O sentido se constrói pela troca linguageira em situação de intercambio social.

O contrato de comunicação é a parte inicial que rege as estratégias discursivas dos meios, já que se propõe a duas finalidades principais: fazer saber (informar o cidadão) e fazer sentir (produzir um objeto de consumo segundo a lógica comercial, captar massas para sobreviver à concorrência). Para Charaudeau (2012) essas duas finalidades são a chamada visada da informação e da captação. A primeira tem o objetivo de informar com credibilidade, trazer para o espaço público midiático aquelas figuras que trazem revelações. Se vale de dois tipos de atividade linguageira, a descrição-narração e a explicação. A visada da captação se dá normalmente pelo desafio da dramatização. A encenação sutil do discurso da informação, com apelos emocionais que fogem a racionalidade e a objetividade a fim de despertar o interesse e a paixão pela informação.

Já o discurso político é o lugar de um jogo de máscaras, de mostra e ocultação de fala (CHARAUDEAU, 2015). Uma forma de organização da linguagem, sistema de pensamento em seu uso para efeitos psicológicos e sociais, no interior de um determina- 
do campo de práticas. Segundo o autor é a situação de comunicação que torna o discurso político, não é o conteúdo do discurso que assim o faz, mas a situação que o politiza.

Para entender essa configuração deve-se voltar à premissa de que a comunicação humana é um teatro, com atos de linguagens, papéis previstos e improvisos. Assim sendo, dependendo da situação de comunicação (e conforme o dispositivo) é que o discurso político vai traçar e desenvolver suas estratégias discursivas. Segundo Charaudeau (2015) o sujeito político que vai proferir o discurso político deve ter entre seus domínios a força da persuasão. Ao passo que, embora nas democracias haja uma preferência pela imagem do candidato, as massas eleitorais também são norteadas por discursos de mitos, imaginários e dotados de crenças. Ao fazer uso da persuasão, esse sujeito político deve se mostrar crível e objetivar influenciar o maior número de indivíduos. Tentar convencer a todos da pertinência de seu projeto político com uma dupla identidade discursiva. Uma que corresponda ao conceito político enquanto lugar de constituição de um pensamento sobre a vida das pessoas e outra que corresponda à prática política, estratégias de gestão de poder, posicionamento ideológico.

O político, em sua singularidade, fala para todos como portador de valores transcendentais: ele é a voz de todos na sua voz, ao mesmo tempo em que se dirige a todos como se fosse apenas o porta-voz de um Terceiro, enunciador de um ideal social. Ele estabelece uma espécie de pacto de aliança entre estes três tipos de voz - a voz do Terceiro, a voz do Tu-todos - que terminam por se fundir em um corpo social abstrato, frequentemente expresso por um Nós que desempenha o papel de guia ("Nós não podemos aceitar que sejam ultrajados os direitos legítimos do indivíduo") (CHARAUDEAU, 2015, p. 80).

Ainda, para Charaudeau (2015), um político precisa inspirar confiança, admiração, aderir à imagem (ethos) ideal do chefe que se encontra no imaginário coletivo dos sentimentos e das emoções. Resumidamente, precisa despertar e gerir as paixões do seu público, o que na prática pode se dar pela dramatização do discurso. As emoções desencadeiam sensações ou comportamentos do interlocutor ou auditório. Assim, o discurso político se utiliza do chamado triângulo da dramaturgia em que encena pelos contos populares - narrativas de aventura, descrição do mal, reparação do mal pelo herói natural ou sobrenatural. O discurso político também insiste na desordem social, na origem do mal e na solução salvadora, na desqualificação do adversário como uma estigmatização da origem do mal. Além disso, faz uso de alguns procedimentos linguísticos (expressivos e enunciativos) para encenar o ethos. 
Os procedimentos expressivos (enunciação da palavra na forma oral, vocalidade) estão relacionados com o bem falar, falar forte, falar tranquilo e falar regional. Para Charaudeau (2015) o bem falar é a qualidade do orador e sua posição elevada na hierarquia social e contribui para a fabricação de um ethos de elite culta e profissional. $\mathrm{O}$ falar forte faz referência ao físico considerável - um porte e certa corpulência capaz de demonstrar força, gestualidade ampla e enérgica, a chamada voz de trovão. Enquanto o falar tranquilo diz respeito ao caráter, inteligência para o qual é requerida uma força de alma interior, com uma dicção lenta. O falar regional envolve o uso do sotaque regional ou do país.

Já os procedimentos enunciativos são aqueles que apresentam o uso de pronomes pessoais de primeira pessoa. A enunciação elocutiva (colocar-se em cena), alocutiva (que implica o interlocutor no mesmo ato de linguagem para fabricar imagens do locutor) e a delocutiva (apresenta o que é dito como se ninguém estivesse implicado. Enunciar uma verdade que não depende do eu).

Ao observar as características centrais do discurso das mídias e também do político notamos que estes são discursos construídos, que se relacionam com fenômenos e esferas sociais. Ambos fazem uso da dramatização, embora essa característica seja primordial no discurso político. O midiático tem respaldo discursivo na informação e, para tanto, faz uso de uma linguagem racional e sedutora para despertar a audiência, numa visada de captação (viés comercial), afetividade. A legitimação dos meios como um lugar que cria e organiza a situação de comunicação e que liga as demais esferas sociais é regulada pelo chamado contrato de comunicação. Já o discurso político para ser reconhecido como tal precisa dessa situação de comunicação, logo, aceita as normativas do contrato. Esse mesmo contrato implica limitações e formatos específicos conforme cada dispositivo midiático. Contudo, ainda que tanto as esferas midiáticas quanto políticas tenham suas estratégias discursivas, a produção de sentido do discurso só se dará na situação de comunicação e conforme a natureza do dispositivo. Nesse estudo, o rádio é o dispositivo em questão.

E, para Charaudeau (2012, p. 106-107) “o rádio é essencialmente voz, sons, música, ruído, e é esse conjunto que o inscreve numa tradição oral”. É por meio desta, do timbre, entonação, fluência que se pode evocar sedução, construir a imagem de si mesmo ou outros efeitos. Ainda conforme o autor, a oralidade é um tipo de troca linguageira particular. Ela exige uma interação verbal na situação de comunicação, revelando as relações que os interlocutores estabelecem entre si na encenação midiática: paixão, razão, polêmica, conivência. Essas trocas, no rádio, se dão em tempo real, entre acontecimento e escuta. 
Para Ferraretto (2014) o rádio tem uma linguagem específica que é essencialmente sonora e que estabelece, acima de tudo, uma relação próxima, um companheiro do ouvinte.

Conforme Charaudeau (2012) o rádio estabelece com a audiência uma intimidade e convivência intelectual, sentimentos de afetividade, emoções, paixão, frieza, mentira, diálogos. E, sendo assim, pode ser considerado a mídia da entrevista, contribuindo para a deliberação democrática pelo fato de ser palavra pura e questionada (com papéis bem definidos - questionador e questionado).

Como esses preceitos se conectam com o discurso das mídias e político? Entendemos que o rádio por ser essencialmente sonoro e por oferecer a possibilidade da escuta em tempo real não dá aos diferentes discursos, ainda que dotados de estratégias, a superioridade de um ou de outro. O momento em si de uma entrevista coloca em cena diferentes atores, pra que possam ser observados enquanto tal, dando abertura para suas respectivas capacidades de influência.

\section{Entrevistas políticas no rádio}

Para aproximar os conceitos de nosso objeto utilizamos os entendimentos de Piatti (2009) sobre a entrevista. Segundo a autora, a entrevista funciona como um jogo de esgrima, marcado pela geração de polêmica e enfrentamento entre entrevistador e entrevistado, ataque (quando o outro responde) e defesa (quando se consegue parar o outro respondendo na mesma linha discursiva ou como oposição). Conforme Piatti (2009) a entrevista jornalística tem uma estrutura própria: interação de perguntas e respostas entre um jornalista e um entrevistado que normalmente é uma figura pública. Apresenta um conteúdo previsível e um tema da atualidade para uma audiência determinada. Tanto entrevistadores quanto entrevistados fazem uso de componentes estratégicos de interação, com objetivos específicos, para construir sua própria imagem e a do interlocutor frente a uma audiência, principalmente em pontos de desacordo. A proximidade com nosso estudo se dá no fato de que, para Piatti (2009) quando se trata de entrevistas com figuras políticas, os jornalistas tendem a polemizar. A ambiência inclui um ritual de confrontação e o uso da dramatização de forças opostas. Conforme Piatti $(2009$, p. 92) a entrevista é um evento de fala particular.

1) Ao contrário das conversações cotidianas, as funções dos participantes estão previamente definidas. As interações são moldadas conforme o cenário, situação.

2) Definidos direitos e obrigações de cada um: quem pergunta e quem responde. 
3) Há um acordo prévio de que o jornalista é regulador da troca, que determina a ordem, a duração e o desenvolvimento do tópico.

4) Ao se produzir para uma audiência a exposição pública aumenta as oportunidades de os participantes construírem sua imagem social ainda que arrisquem perdê-la. As interações e os confrontos são conduzidos a partir das perguntas do entrevistador. As perguntas é que caracterizam as entrevistas como gêneros, enquanto algumas provocam o gênero narrativo, outras incitam a opinião (grau de polêmica variável já que pode ser consistente ou não para o jornalista). O grau de menor tensão se dá no grau narrativo, que busca informações sobre fatos. O jornalista pode criar uma série de perguntas que incitem a opinião do entrevistado, o chamado “bombardeio' de perguntas. Para a autora, nessas situações, há uma estrutura tríade de análise (ação, reação/oposição e defesa). O jornalista pode incitar a polêmica usando de estratégias como intensificação, interrupções, reformulações corretivas, perguntas hostis, interrogatório sobre os fatos, entre outras. Segundo Piatti (2009) a polêmica se instaura não na opinião, mas nas versões sobre o tema. Enquanto isso, as respostas (parte da reação) dos entrevistados também vão utilizar de diferentes estratégias como a contação de história - uma forma de emitir opinião, sem dizer uma frase de efeito ou uma opinião explícita. Ou seja, uma forma evasiva de não responder.

A entrevista pode ser considerada como um jogo: é organizado por meio de regras, integradas por movimentos e contra-movimentado, onde seus participantes cooperam ou competem com níveis variados de habilidade e implementar seus movimentos estratégicos para alcançar um certo objetivo (PIATTI, 2009, p. 101).

Na entrevista também se faz uso de argumentos (de retórica e de oposição) e opiniões. Charaudeau (2012) destaca, dentro da entrevista, um subgênero, a entrevista política, que presume pôr à disposição da opinião pública uma série de julgamentos e de análise que justifiquem o engajamento do entrevistado. Esse gênero se baseia então num "é-preciso-dizer-a-qualquer-preço" (CHARAUDEAU, 2012, p. 215). Além disso, esse tipo de entrevista está relacionado com a vida cidadã, identidade do entrevistado. Um ator representante de si mesmo ou de um grupo, com poder de decisão ou pressão. Espera-se que o entrevistador vá tentar tirar do entrevistado o máximo de informações, mostrar intenções ocultas, jogo de questionamento sutil. Também vai se utilizar da chamada falsa inocência, provocação, rebater as posições contraditórias do convidado. Conforme McLeish (2001) a entrevista política tem que representar uma contribuição à sociedade democrática. 
Com base nesses preceitos teóricos é que desenvolvemos, no próximo item, a análise da entrevista feita no Gaúcha Atualidade, durante o julgamento do ex-presidente Lula. Consideramos as estratégias do discurso midiático, político, a atuação do programa como ator político e as trocas sociais que se dão na situação de troca entre campo político e midiático.

\section{Gaúcha Atualidade e a entrevista com o vice-presidente do PT, Alexandre Padilha, durante a semana o julgamento de Lula do TRF4}

O programa surge em $1^{\circ}$ de agosto de 1977, na Rádio Gaúcha, ainda com o nome de Atualidade. Assim como o programa Agora (da Rádio Guaíba), constituem-se nos principais espaços dedicados às entrevistas sobre política e economia no rádio do Rio Grande do Sul (FERRARETTO, 2007, p. 464). É comandado, desde 2013, pelo editor-chefe da Rádio Gaúcha, Daniel Scola, contempla assuntos do cotidiano e interesse público sendo que o formato atual inclui a participação dos ouvintes via sites de redes sociais e aplicativos ${ }^{4}$. Tem quadros fixos: uma entrevista principal, espaço de economia, trânsito e esporte, participação dos repórteres que acompanham os principais acontecimentos na cidade de Porto Alegre e região metropolitana. A apresentação do programa é dividida entre três âncoras; Daniel Scola, Rosane de Oliveira (comentarista política) e Carolina Bahia (correspondente do Grupo RBS em Brasília).

A semana do julgamento do ex-presidente Lula foi marcada por grande movimentação e repercussão na cidade de Porto Alegre e no TRF4. Além de ser um acontecimento político nacional com destaque da imprensa local, estadual, nacional e internacional ${ }^{5}$. Conforme GaúchaZH $(2018)^{6}$ Porto Alegre recebeu inúmeras caravanas de apoiadores do ex-presidente, além de uma cobertura jornalística feita por mais de trezentos jornalistas do país e do Exterior. O julgamento, em segunda instância, no TRF4, foi um apelo de Lula e sua defesa para tentar reverter a primeira condenação criminal, em 2017, pelo juiz federal Sérgio Moro, de nove anos e meio de prisão

4. O programa também dispõe de perfil no Facebook, administrado pelo produtor e pelos outros âncoras, além de disponibilizar as informações do programa via redes sociais digitais da Rádio Gaúcha, no site da emissora. Também é transmitido via Live no Facebook.

5. Outros detalhes em: https://www.coletiva.net/especiais-julgamento-de-lula-pela-imprensa/imprensa-nacional-mobilizada-na-cobertura-do-julgamento-de-lula-na-capital,234193.jhtml. Acesso em 2 mar 2018.

6. Disponível em < https://gauchazh.clicrbs.com.br/politica/noticia/2018/01/julgamento-de-lula-no-trf4-a-semana-em-que-os-olhares-se-voltam-ao-rs-cjcpg3ktt00nw01lk9p8yuyw2.html>. Acesso em 15 fev. 2018. 
por corrupção passiva e lavagem de dinheiro. O julgamento aconteceu no dia 24 de janeiro de 2018, mas as caravanas de apoio, esquemas de segurança e cobertura intensificada da imprensa se deu durante toda aquela semana (entre 22 e 26 de janeiro). Além disso, no dia 23 de janeiro (vésperas do julgamento) Lula veio a Porto Alegre e discursou, durante ato, na Esquina Democrática, para apoiadores, simpatizantes e lideranças partidárias.

A cobertura da Rádio Gaúcha movimentou inúmeros profissionais (especialmente repórteres) durante a semana. O Gaúcha Atualidade destinou a entrevista principal do programa, na semana, para fontes relacionadas ao caso. No dia 22 de janeiro, o entrevistado foi o vice-presidente do Partido dos Trabalhadores (PT), Alexandre Padilha que falou sobre a visita de Lula em Porto Alegre, no dia 23. A referida entrevista foi analisada a partir de um esquema protocolar, construído a partir das teorias acima sintetizadas conforme os quadros subsequentes.

\section{Categorias de análise para as entrevistas}

Como já visto, o discurso midiático tem dois mecanismos centrais: a visada da informação e da captação. Já o discurso político se vale primordialmente do triângulo da dramaturgia (emoções, paixões) encenando o ethos (imagem) por meio de procedimentos linguísticos (expressivos e enunciativos). Neste sentido, neste item, considerando a situação de comunicação e a dramatização das forças, buscamos identificar as estratégias utilizadas por ambos os discursos, pontuando as que aparecem na entrevista, permitindo visibilidade social e ao mesmo tempo impondo formatações aos discursos.

A entrevista é um jogo de esgrima, com polêmica, enfrentamento entre entrevistador e entrevistado, interação de perguntas e respostas entre jornalista e entrevistado (figura pública). Ambos buscam construir sua imagem frente à audiência. Também é preciso observar o grau de polêmica presente nas entrevistas, o confronto e a dramatização das forças opostas e a regulação por parte do jornalista que conduz a entrevista, que pode ter um tom tanto narrativo e opinativo.

Apresentamos, na Tabela 1, as estratégias do discurso midiático e do político, segundo Charaudeau (2012 e 2015), encontradas na entrevista com o vice-presidente nacional do PT. 
Tabela 1. Entrevista com Alexandre Padilha

\begin{tabular}{|c|c|}
\hline $\begin{array}{c}\text { Discurso Midiático } \\
\text { Entrevistadores/âncoras: Daniel Scola, } \\
\text { Rosane de Oliveira e Carolina Bahia. }\end{array}$ & $\begin{array}{l}\text { Discurso Político } \\
\text { Entrevistado: Alexandre Padilha }\end{array}$ \\
\hline $\begin{array}{c}\text { Daniel: Como é que vai ser a presença do ex- } \\
\text { presidente Lula aqui em Porto Alegre, o que está } \\
\text { previsto? } \\
\text { Ele chega em Porto Alegre no fim da tarde, ele } \\
\text { participa de um ato no centro da capital. O que ele } \\
\text { vem dizer aos seus apoiadores aqui no Rio Grande } \\
\text { do Sul?"” } \\
\text { Estratégia: Visada de informação }\end{array}$ & $\begin{array}{c}\text { O presidente Lula nos comunicou ontem o } \\
\text { desejo de vir a Porto Alegre percebendo toda a } \\
\text { solidariedade nacional. Ficou muito emocionado } \\
\text { com as caravanas. } \\
\text { Então ele nos comunicou o desejo de vir aqui } \\
\text { para agradecer, agradecer profundamente a } \\
\text { solidariedade, o posicionamento dos juristas, } \\
\text { dos intelectuais, da população que vem a Porto } \\
\text { Alegre. } \\
\text { Onde teremos aí, a partir das cinco e meia, } \\
\text { uma grande manifestação com lideranças } \\
\text { nacionais de vários partidos. Que inclusive não } \\
\text { necessariamente defendem o presidente Lula } \\
\text { como candidato, mas que defendem o direito } \\
\text { do presidente Lula ser candidato. Um homem } \\
\text { inocente, e nesse sentido, defende o direito das } \\
\text { pessoas que querem votar no presidente Lula } \\
\text { poder votar nele nas eleições. }\end{array}$ \\
\hline $\begin{array}{c}\text { Rosane: “...essa vinda do ex-presidente Lula } \\
\text { aqui, ela vinha sendo programada antes, mas há } \\
\text { uma dúvida em relação ao julgamento. O senhor } \\
\text { já tem a definição de onde ele vai acompanhar o } \\
\text { julgamento? Já se sabe que é em São Paulo. Mas } \\
\text { será em local público? Ele vai ficar em casa? Como } \\
\text { vai ser? }\end{array}$ & $\begin{array}{c}\text {... ainda está definindo o local. Vai estar com } \\
\text { a família, com os filhos. Faz quase um ano } \\
\text { que a Dona Marisa morreu. Inclusive, dia } 24, \\
\text { foi o dia que a Dona Marisa teve o acidente } \\
\text { vascular cerebral. Eu me lembro como se fosse } \\
\text { hoje, recebendo a notícia, indo para o hospital } \\
\text { acompanhar o caso da Dona Marisa. } \\
\text { Então, após o julgamento independente de qual } \\
\text { seja o resultado, ele receberá também um abraço } \\
\text { do povo paulista [...]. }\end{array}$ \\
\hline Estratégia: Visada de informação & $\begin{array}{c}\text { Estratégia: emoção no discurso, narrativa de } \\
\text { herói natural }\end{array}$ \\
\hline
\end{tabular}




\begin{tabular}{|c|c|}
\hline $\begin{array}{l}\text { Daniel Scola e Rosane de Oliveira questionam } \\
\text { sobre o julgamento } \\
\text { Estratégia: Visada de informação }\end{array}$ & $\begin{array}{l}\text { Oh, Rosane. São duas questões aqui do ponto } \\
\text { de vista jurídico, criminal, penal. Nós temos } \\
\text { plena consciência da inocência do presidente } \\
\text { Lula. A Justiça Federal de Brasília recentemente } \\
\text { tomou uma decisão clara, que o apartamento não } \\
\text { é do presidente Lula e o próprio TRF4 [...] em } \\
\text { sentença recente estabeleceu claramente que só é } \\
\text { proprietário do imóvel quem tem o registro dele. } \\
\text { [...] nós acreditamos e esperamos com coerência } \\
\text { do TRF4 a absolvição do presidente Lula. } \\
\text { [...] O PT irá registrar, pode registrar o presidente } \\
\text { Lula como sendo candidato em agosto. } \\
\text { Estratégia: herói natural, desordem social. Uso de } \\
\text { procedimento expressivo: falar forte. }\end{array}$ \\
\hline $\begin{array}{l}\text { Rosane: e a Lei da Ficha Limpa, ministro? O } \\
\text { que ela prevê é que se a pessoa é condenada por } \\
\text { colegiado, no caso que é aqui, a Oitava Turma do } \\
\text { TRF4 é um colegiado em segunda instância, ela se } \\
\text { torna ficha suja a partir desse momento. } \\
\text { Estratégia: Visada de informação }\end{array}$ & $\begin{array}{c}\text { [...] Cabem recursos da decisão do TRF4 } \\
\text { e também vai caber recurso no Tribunal } \\
\text { Eleitoral. Então, estão tentando colocar o PT } \\
\text { numa armadilha que é começar a construir na } \\
\text { população a ideia de que o presidente Lula não } \\
\text { poderá ser candidato. } \\
\text { [...] O presidente Lula vai continuar nas suas } \\
\text { caravanas. [...]. } \\
\text { Estratégia: solução salvadora, herói natural. }\end{array}$ \\
\hline $\begin{array}{l}\text { Daniel: Ontem, em entrevista [...] o ex-governador } \\
\text { do Rio Grande do Sul, Olívio Dutra, disse que o } \\
\text { PT errou ao não ter construído nesse meio tempo, } \\
\text { desde a condenação em primeira instância, até } \\
\text { agora, uma candidatura alternativa à presidência } \\
\text { da República. O senhor não trabalha com outra } \\
\text { hipótese. O candidato é o ex-presidente Lula? }\end{array}$ & $\begin{array}{l}\text { Não só eu como o povo brasileiro, quase metade } \\
\text { do povo brasileiro quer a volta do presidente. [...] } \\
\text { O Presidente Lula é plano A da metade do povo } \\
\text { brasileiro. } \\
\text { Estratégia: emoção, procedimento expressivo de } \\
\text { falar forte, procedimento enunciativo (se coloca } \\
\text { em cena). }\end{array}$ \\
\hline
\end{tabular}




\section{Daniel: Metade?}

Estratégia: Visada de informação e captação.

As pesquisas, quase metade, $42,43 \%$ tem estados que chega a $70,80 \%$. Então o povo brasileiro quer, metade do povo brasileiro quer a volta do presidente Lula e é por isso que o PT tem conviç̧ão de que o presidente Lula é aquele que tem maior capacidade de superar a crise política, institucional que o Brasil vive.

Ontem saiu um dado gravíssimo, são mais de 300 mil empregos perdidos em 2017. A tal da reforma trabalhista que era para ampliar a geração de empregos, [...] Ou seja, o país não retomou o crescimento.

nós estamos vivendo a maior crise em relação a febre amarela que demonstra claramente uma falta de produção de vacina, de uma vacina que é produzida pelo próprio Ministério da Saúde [...].

Estratégia: emoção, desordem social, origem do mal, herói natural.

Rosane: [...] O senhor fala...do fato do expresidente Lula liderar as pesquisas, mas ao mesmo tempo, nas mesmas pesquisas mostram que ele é o que tem de maior rejeição. Ele ainda, além desse processo, responde a cinco outros processos. Vocês têm dito que se trata de uma campanha para excluir o presidente, mas é um processo que parte de denúncias e delações feitas, inclusive por ex-companheiros, ex-ministros, como é o caso do ministro Palocci. Não fechou a delação mas fez revelações extremamente graves. E também partem de acusações feitos por empreiteiros que trabalharam para o governo. [...] desde que Sérgio Moro condenou o ex-presidente Lula, sempre se soube que o apartamento não estava em nome dele. Mas o argumento que a gente tem ouvido dos [...] juristas consideram a sentença correta é de que a corrupção passiva se caracteriza mesmo quando o negócio não chega até o final pela simples negociação de vantagens. E que é isso que o Leó Pinheiro disse que teria ocorrido. Então, como se defende o ex-presidente desta acusação de que houve a negociação, de que o apartamento era pra ele, mas que foi abortado justamente porque isso se tornou alvo da Lava-Jato? Estratégia: Visada da informação
Rosane, tenho certeza absoluta de todas essas acusações, delações, cairão no mesmo vazio que está caindo a história do tripléx. Se dizia que o tríplex era do Lula, que tinha definido a reforma.

Aí o Ministério Público listou mais de 70 testemunhas que iriam comprovar a convicção do Ministério Público. As setenta testemunhas que foram depor junto ao juiz Sergio Moro disseram claramente, todas elas, que o apartamento não tinha nenhuma relação com os contratos da Petrobrás.

Estratégia: Procedimento expressivo de falar forte e falar bem. 
Rosane: Quais, qual é a relação do presidente Lula com a OAS? Porque nós vimos nas trocas de e-mails de executivos da OAS que nos depoimentos deles, nós vimos nos documentos deles recolhidos pela investigação. Qual era afinal a relação do expresidente Lula com a OAS?

Estratégia: Visada da informação

Rosane: O senhor foi colega do Palocci de ministério. Era um homem de confiança do expresidente, [...] era homem de confiança da expresidente Dilma. Conviveu com senhores. Foi um dos autores da carta ao povo brasileiro. Como é que vocês receberam a informação de que o Palocci agora mudou de lado e está dizendo sim, o Lula sabia que entrava dinheiro ilegal na campanha. $\mathrm{O}$

Lula sabia desses esquemas de corrupção?

Estratégia: Visada da informação e captação
Não tem nenhuma vantagem ou própria. Tinham as relações de um presidente da República com empresas importantes. A OAS e outras empresas são empresas importantes, de investimento no país, relação absolutamente institucional. Como não, é a defesa que está falando isso, mais de setenta testemunhas listadas durante o processo que foram depor diante do juiz Moro, disseram claramente, o presidente Lula não tem nenhuma relação, vantagem do presidente Lula com a OAS.

Estratégia: Procedimento expressivo de falar bem e falar forte.

Rosane, com profunda indignação, de alguém que por durante anos participou do governo, teve papeis importante no governo e na medida que foi preso, teve a sua privação da liberdade, foi apresentado a proposta de delação vem com uma lista de mentiras, que não se sustentam. [...] Mais uma vez tentam empurrar o presidente Lula, um crime, que as provas não aparecem e o crime não existe. Não à toa, os advogados de defesa têm frizado claramente uma perseguição jurídica, política ao presidente Lula, no sentido único e exclusivo de impedi-lo de disputar as eleições.

Estratégia: emoção, desordem social

Fonte: autoria própria

Ao observarmos os trechos na fala dos âncoras e entrevistado, pontuamos as estratégias de visada de captação e informação do discurso midiático e o uso da emoção se sobressaindo na fala de Alexandre Padilha. No discurso midiático prevaleceu a visada da informação (aparece em seis dos nove trechos centrais da entrevista). Conforme Charaudeau (2012) é um modo de reportar acontecimentos, que também implica o contrato midiático, já que se espera que os entrevistadores façam questões fechadas, diretas. Essa estratégia aparece na primeira pergunta da entrevista feita pelo âncora Daniel Scola, "como é que vai ser a presença do ex-presidente Lula aqui em Porto Alegre, o que está previsto?”.

Uma enunciação com escolha de palavras que, neste caso, objetivam a descrição-narração, esclarecimento. Mas a visada da informação também ganha representação em trechos como: "essa vinda do ex-presidente [...] ela vinha sendo programada antes", “definição de onde ele vai acompanhar o julgamento? Já se sabe que é em São Paulo", 'Lei da Ficha Limpa [...] ela prevê que se a pessoa é condenada por colegiado [...] ela se torna ficha suja", "metade?”, “ex-presidente Lula liderar as pesquisas, [...] nas mesmas 
pesquisas mostram que ele é o que tem maior rejeição, "além desse processo responde a cinco outros processos", "O Lula sabia dos esquemas de corrupção?”.

Há também uma retomada da visada da informação, de buscar esclarecimentos, contrapor as versões apresentadas pelo entrevistado, questionar, esclarecer a audiência. Mais do que isso, aqui também se observa a estratégia da buscar se colocar como um meio credível, ainda que as questões carreguem pontos de dramatização. Como antevisto por Charaudeau (2012), ainda que em caráter informativo, a mídia transita entre os dois polos. Essa marca é presente nos trechos destacados.

No discurso político, representado por Alexandre Padilha, prevalece o discurso da emoção e o triângulo da dramaturgia, de apresentar o ex-presidente Lula, a vinda a Porto Alegre e o julgamento numa narrativa heroica. Algumas expressões marcam a fala como um todo, por exemplo, "receber abraço do povo paulista", "emocionado", "agradecer profundamente a solidariedade", "um homem inocente", "vai estar com a família, com os filhos", "nós temos plena consciência da inocência do presidente Lula", "estão tentando colocar o PT numa armadilha", "não só eu como o povo brasileiro, quase metade do povo brasileiro quer a volta do presidente", "mais uma vez tentam empurrar o presidente Lula, um crime que as provas não aparecem e o crime não existe".

Cabe ponderar que todas as falas são conduzidas e resultam da interação entre apresentadores e entrevistado. E essa dinâmica própria permite pontuar o grau de polêmica da situação, quando para além de informar o jornalista parte para outra estratégia, a captação, que a partir da fala do entrevistado ou por iniciativa própria passa a dramatizar a interação. Aqui percebemos a dinâmica descrita por Piatti (2009), a entrevista como um jogo de esgrima, de ataque e contra-ataque, que exige, por exemplo, o falar bem e o falar forte de Alexandre Padilha e também dos âncoras. Quando Daniel Scola fala "Ontem, em entrevista [...] o ex-governador do Rio Grande do Sul, Olívio Dutra, disse que o PT errou ao não ter construído nesse meio tempo, desde a condenação em primeira instância, até agora, uma candidatura alternativa à presidência da República" o mesmo quer questionar sobre outro possível candidato pelo partido, mas também, abre espaço para uma declaração polêmica e que vai exigir do entrevistado o que já foi pontuado, o falar bem, forte e o uso da dramaturgia como estratégia de defesa. A visada da informação também compreende um ataque, considerando a entrevista como um jogo de esgrima porque ela estimula a resposta do entrevistado e esta pode vir como um contra-ataque, o qual numa entrevista política vai ser fortemente permeada pelo triângulo da dramaturgia.

Em vias gerais, esta primeira entrevista, demarca as várias facetas do discurso 
político, midiático e das interações singulares que permeiam as trocas simbólicas. O grau de polêmica pode ser entendido como uma caraterística da entrevista política. Se pensarmos a atuação da emissora enquanto ator político na situação de entrevista, nota-se que sua construção é permeada pela visada da informação, que encontra espaços para formar o que podemos denominar como auge da entrevista, marcada pelo grau de polêmica e pelas alterações nas falas tanto da fonte política quanto dos entrevistadores. O início do ponto máximo de polêmica da entrevista é quando Rosane de Oliveira questiona Alexandre Padilha se uma pessoa condenada em segunda instância por colegiado se torna ficha suja.

\section{Considerações finais}

Nesta análise é perceptível a situação de entrevista política como um jogo de ataque e contra-ataque. Jogo este no qual as partes envolvidas vão construindo estratégias para vencer ou convencer o adversário (tanto entrevistadores como entrevistados). Embora a dramaturgia seja característica fundamental do discurso político percebemos que ela também envolve a fala dos entrevistadores, que trabalha com a emoção. Essa perspectiva aparece na fala de Rosane de Oliveira quando questiona como um ex-companheiro pode ter dado um depoimento em tom de acusação contra o ex-presidente Lula e quando coloca em cena uma liderança do partido que tem posições e declarações conflitantes das apresentadas pelo vice-presidente do partido. São pontos de clímax da situação de entrevista e que vão, enquanto processo interacional, destacando as forças do rádio ou da emissora agindo como um ator político.

A mesma dramaturgia, enquanto triângulo da dramaturgia do discurso político (desordem social, na origem do mal e na solução salvadora) aparece na entrevista, pela fala de Alexandre Padilha. A sua narrativa de defesa e estratégia de jogo é apresentar a ideia de que o julgamento representa uma desordem social já que pode impedir que o ex-presidente, em caso de condenação, possa são ser mais candidato nas próximas eleições presidenciais. E que a situação em si representa a origem para essa desordem. O entrevistado apresenta a narrativa de solução salvadora, afirmando que o ex-presidente Lula está sendo vítima e luta heroicamente para que a ordem social seja reestabelecida. A dramaturgia torna-se uma estratégia e ao mesmo tempo um produto da entrevista política no rádio, ela tem a finalidade de envolver a audiência, espectadora do jogo interacional. 


\section{Referências}

BORRAT, Hector. El periódico, ator político. Barcelona: Editorial Gustavo, 1989.

CHARAUDEAU, Patrick. Discurso das mídias. Tradução Angela S. M. 2. ed., 1. reimpressão. São Paulo: Contexto, 2012.

CHARAUDEAU, Patrick. Discurso Político. Tradução Fabiana K. e Dilson F. C e 2. ed., 2. reimpressão. São Paulo: Contexto, 2015.

FERRARETTO, Luiz Artur. Rádio e capitalismo no Rio Grande do Sul: as emissoras comerciais e suas estratégias de programação na segunda metade do século 20. Canoas: Ed. Ulbra, 2007.

GAÚCHAZH. Julgamento de Lula no TRF4: a semana em que os olhares se voltam ao RS. Disponível em: https://gauchazh.clicrbs.com.br/politica/noticia/2018/01/julgamento-de-lula-no-trf4-a-semana-em-que-os-olhares-se-voltam-ao-rs-cjcpg3ktt00nw01lk9p8yuyw2.html. Acesso em: 15 fev. 2018.

MCLEISH, Robert. Produção de Rádio - Um Guia Abrangente de produção radiofônica. São Paulo: Summus Editorial, 2001.

PIATTI, Guillermina. La entrevista radiofónica como esgrima verbal: estructura y función de los episódios Polémicos. Revista Onomazéin, Chile, n.19, 2009, p. 89-110. 